\title{
Заходи профілактики та ліквідації інтраопераційних і післяопераційних ускладнень при VATS у хворих на туберкульоз легень
}

Опанасенко М.С., Лисенко В.І., Терешкович О.В., Конік Б.М., Леванда Л.І., Шамрай М.Ю., Білоконь С.М. ДУ «Національний інститут фтизіатрії і пульмонології ім. Ф.Г. Яновського НАМН України», м. Київ, Україна

Мета. Визначити ефективні заходи профілактики та ліквідації інтраопераційних і післяопераційних ускладнень при застосуванні VATS у хворих на туберкульоз (ТБ) легень.

Матеріали та методи. Iз 2008 по 2020 р. фтизіатричним пацієнтам було виконано 133 VATS-операції, а саме: атипова сегментектомія - 29 (21,6 \%) випадків, типова сегментектомія - 49 (36,9 \%), лобектомія - 49 (36,9 \%), білобектомія - 2 (1,5 \%), пульмонектомія - 4 (3,1 \%). Хворих із діагнозом уперше діагностованого ТБ було 62 (46,3 \%), із множинною лікарською стійкістю - 45 (34,4 \%), із широкою лікарською стійкістю - 26 (19,3 \%). Інтраопераційні ускладнення було зафіксовано в 5 (3,8 \%) пацієнтів: 2 інтраопераційні кровотечі та 3 надриви паренхіми легені. Післяопераційні ускладнення було виявлено у 21 хворого (16,1%): пізнє розправлення легені - 4 (3,1 \%), післяопераційний плевральний випіт - 4 (3,1 \%), дихальна недостатність 3 (2,3 \%), дисбіоз кишківника - 1 (0,8 \%), серома післяопераційної рани - 2 (1,5 \%), нагноєння післяопераційної рани 5 (3,8 \%), неспроможність кукси бронха із залишковою плевральною порожниною - 2 (1,5%). Ефективність лікування становила $96,9 \%$.

Результати та їх обговорення. Для профілактики ускладнень при VATS потрібно зважено відбирати пацієнтів для Втручання, оцінювати рентгенологічну картину патологічних змін на доопераційному етапі, визначати безпечну ділянку для встановлення першого торакопорту. Важливими $є$ виконання зручного мініторакотомного доступу довжиною до 8 см у V або VI міжребер'ї та використання ранорозширювачів невеликого розміру. Ретельна лімфодисекція в корені частки легені, пересічення та прошивання виділених окремих елементів кореня легені $\epsilon$ запорукою спроможності та міцності механічного шва. Передопераційна корекція гемостазу залежно від віку, ваги, супутньої патології $\epsilon$ невід'ємною складовою профілактики порушень згортання крові та полягає в застосуванні гепатопротекторів, антиагрегантів й антикоагулянтів. За неможливості виконання VATS-пневмолізу, роздільної обробки елементів кореня легені, труднощів у досягненні гемостазу конверсія в широку торакотомію $є$ надійним і дієвим методом профілактики різноманітних ускладнень. Вчасне застосування конверсії в торакотомію, накладання П-подібних швів, реVATS або реторакотомія, гемостатична терапія, активна аспірація, накладання штучного пневмоперитонеуму, додаткове дренування плевральної порожнини чи повторні пункції, ФБС, клапанна бронхоблокація, корекція антибактеріальної терапії, використання пробіотиків, корекція схем протитуберкульозної терапії, хірургічна обробка ран, а також комбінація цих заходів допомагають ефективно та надійно ліквідувати як інтра-, так і післяопераційні ускладнення при VATS.

Висновки. На безпечність і зручність VATS впливають багато факторів. Адекватна оцінка можливості виконання такої операції, методи профілактики ускладнень та їх своєчасне застосування забезпечують прогнозований перебіг післяопераційного періоду та зменшення частоти ускладнень. Залежно від причини вчасне застосування різних методів ліквідації інтра-та післяопераційних ускладнень дає можливість ефективно та надійно розв'язати проблему. Використовуючи ці практичні методи, можна визначити правильну тактику операції та ведення післяопераційного періоду, що в результаті вплине на загальну ефективність лікування. 